\title{
Concordant Copy Number and Transcriptional Activity of Genes Mapping to Derivative Chromosomes 8 During Cellular Immortalization In Vitro
}

\author{
Lesa Begley, ' David Keeney, ' Ben Beheshti, ${ }^{2}$ Jeremy A. Squire, ${ }^{2}$ Rajiv Kant,' Hassan Chaib, 'James W. MacDonald, \\ Johng Rhim, ${ }^{4}$ and Jill A. Macoska ${ }^{1,3 *}$ \\ 'Department of Urology, University of Michigan, Ann Arbor, Michigan \\ ${ }^{2}$ Ontario Cancer Institute, University of Toronto, Toronto, Ontario, Canada \\ ${ }^{3}$ Comprehensive Cancer Center, University of Michigan, Ann Arbor, Michigan \\ ${ }^{4}$ Center for Prostate Disease Research, USUHS, Rockville, Maryland
}

Deletion, rearrangement, or amplification of sequences mapping to chromosome 8 are frequently observed in human prostate and other tumors. However, it is not clear whether these events alter the transcriptional activity of the affected genes. To examine this question, we have utilized oligonucleotide microarray technology and compared the transcriptional patterns of normal human prostate tissues and five immortalized cell lines carrying either two normal chromosomes 8 or one normal and one derivative chromosome 8 . Comparison of the transcriptional profiles of the tissues and cell lines identified 125 differentially expressed transcripts specific to chromosome 8 , with 46 transcripts mapping to 8p and 79 transcripts mapping to 8q. The majority of genes mapping to $8 p(44 / 46,96 \%)$ were transcriptionally down-regulated in cells hemizygous for $8 p$, whereas the majority of genes mapping to $8 \mathrm{q}(58 / 79,73 \%)$ were up-regulated in cells carrying three copies of $8 q$. Moreover, hemizygous alleles on $8 p$ exhibited sub-haploinsufficient transcript levels for several genes that could be induced to haploinsufficient levels under hypomethylating conditions, suggesting that epigenetic regulation is a common mechanism for gene silencing in cells deleted for one copy of 8p. The results of these studies clearly demonstrate that alterations of gene copy number and transcriptional activity are directly correlated in cell lines harboring derivative chromosomes 8 , and that these events are commonly observed during cellular immortalization in vitro. () 2005 Wiley-Liss, Inc.

\section{INTRODUCTION}

A PubMed search conducted in March 2005 identified 170 citations linking chromosome 8 and human prostate cancer, the most citations for any chromosome. Many of these studies have clearly demonstrated that deletion, rearrangement, or amplification of sequences mapping to chromosome 8 are frequently observed in human prostate and other tumors (Bergerheim et al., 1991; Wolman et al., 1992; Bova et al., 1993; Macoska et al., 1993, 1994; MacGrogan et al., 1994; Sakr et al., 1994; Trapman et al., 1994; Bova et al., 1996). Several studies have identified discrete or large deletions of the short arm of chromosome 8 , suggesting that one or more tumor-suppressor genes critical for prostate tumorigenesis map to $8 \mathrm{p}$. Even so, only a few genes have been identified thus far as candidate tumor-suppressor genes mapping to $8 \mathrm{p}$, including NKX3.1 at $8 \mathrm{p} 21$, LZTS1 at $8 \mathrm{p} 22$, and MSR1 at 8p22 (He et al., 1997; Ishii et al., 1999; Xu et al., 2002). Other studies have demonstrated amplification for all or part of the long arm of chro- mosome 8 in prostate tumors, suggesting that one or more oncogenes important for prostate tumorigenesis map to 8q (Macoska et al., 1994; Takahashi et al., 1994). In particular, amplification of the 8q24.21 region harboring the $M Y C$ oncogene has been implicated as an independent prognostic factor predictive for prostate tumor recurrence, metastasis, and poor patient outcome (Jenkins et al., 1997; Sato et al., 1999).

Although the studies cited above successfully defined regions of genomic loss or gain involving chromosome 8 , they did not globally examine the potential effects of these large dosage changes on

*Correspondence to: Jill A. Macoska, Ph.D., Department of Urology, University of Michigan, 6217 CCGC, 1500 East Medical Center Drive, Ann Arbor, MI 48109-0944. E-mail: jcoska@umich.edu

Supported by: National Institutes of Health; Grant numbers: 5 R01 CA60948, 1R21 DK59139, 5P30 CA46592, and Department of Defense; Grant number: DAMD 17-99-1-9520 (to J.A.M.); National Cancer Institute of Canada; Canadian Cancer Society (to J.A.S.).

Received 20 August 2004; Accepted 31 August 2005

DOI 10.1002/gcc.20274

Published online 18 October 2005 in

Wiley InterScience (www.interscience.wiley.com). 
the transcriptional levels of genes mapping to these sequences. This deficiency can be addressed by the use of high-throughput technologies, which now permit the dual analysis of genomic and transcriptional alterations in human tumors. Using these techniques, we and our colleagues have shown that reduction to hemizygosity and transcriptional down-regulation for genes mapping to $8 \mathrm{p}$ is largely coincident in human prostate tumors and that genes mapping within the 8p11-p12 amplicon are largely transcriptionally up-regulated in three human breast cancer cell lines (Chaib et al., 2003; Ray et al., 2004).

We now report the utilization of high-throughput techniques for precisely "mapping" the transcriptional levels of genes on $8 \mathrm{p}$ and $8 \mathrm{q}$ for normal and derivative chromosomes 8 in normal human prostate tissues and immortalized human prostate epithelial cell lines. These studies show that alterations of gene copy number and transcriptional activity are directly correlated in cell lines harboring derivative chromosomes 8 . Moreover, several genes mapping to hemizygous alleles on $8 \mathrm{p}$ exhibited sub-haploinsufficient transcript levels that could be induced to haploinsufficient levels under hypomethylating conditions, suggesting that epigenetic regulation is a common mechanism for gene silencing in cells deleted for one copy of $8 \mathrm{p}$. Taken together, these observations suggest that alterations in copy number and transcriptional activity of genes mapping to derivative chromosomes 8 are associated with human prostate epithelial cellular immortalization in vitro.

\section{MATERIALS AND METHODS}

\section{Establishment of Cell Cultures}

Normal prostate tissue samples were obtained aseptically from patients undergoing radical prostatectomy after cancer diagnosis. All tissue acquisition and processing protocols conformed to those reviewed and approved by the University of Michigan Institutional Review Board. The tissue was minced into pieces $<1 \mathrm{~mm}^{2}$; one piece was fixed in $5 \%$ formalin for further histopathological evaluation, whereas the rest was plated into $60-\mathrm{mm}$ plates coated with Vitrogen 100 (Cohesion Laboratories, Palo Alto, CA) in keratinocyte growth medium supplemented with bovine pituitary extract, epidermal growth factor (EGF), and antibiotics (Invitrogen, Carlsbad, CA). Cultures that exhibited both fibroblastic and epithelial cell populations were subjected to brief trypsinization for removal of fibroblast cells. Cells were immortalized through transduction with the recombinant LXSNE6E7 retrovirus harboring the human papilloma virus E6 and E7 genes as described previously (Bright et al., 1997). Transduced cells were selected by use of $400 \mu \mathrm{g} / \mathrm{ml}$ geneticin. After an initial round of cell death and crisis, cells resistant to geneticin grew out and were considered immortal after 10 passages. Immortalized cell cultures were diluted 1:24 and individual subclones established. Selected subclones were plated into sterile chamber slides, grown to $~ 80 \%$ confluency, fixed in $50 \%$ methanol/ $50 \%$ acetic acid, and stained using a pan-cytokeratin monoclonal antibody mixture containing clones C-11, PRK-26, CY-90, KS-1A3, M20, and A53-B/A2 for detection of epithelial cells, or a monoclonal antivimentin antibody (Sigma-Aldrich, St. Louis, $\mathrm{MO})$ for detection of stromal fibroblastic cells. A representative subclone homogenously staining with the pancytokeratin antibodies but not the antivimentin antibody was chosen from each culture for further analysis. Cells at the following passage numbers (where $\mathrm{p}$ indicates passage) were used for all experiments: N15C6 early, < p25; N15C6 late, > p40; N17A3, p25-p30; N33B2, p25p30; 1532T, p40-45; 1542T, p40-45.

\section{Spectral Karyotyping Analysis}

Spectral karyotyping (SKY) analysis was carried out on previously G-banded slides. Images were captured, and the microscope coordinates were noted. Residual oil was removed with xylene, followed by destaining with methanol. The slides were then rehydrated in a descending ethanol series and fixed with $1 \%$ formaldehyde in a $50 \mathrm{mM}$ $\mathrm{MgCl}_{2} /$ phosphate buffer solution for $10 \mathrm{~min}$. Slides were dehydrated and denatured for 30-45 sec at $75^{\circ} \mathrm{C}$ in $70 \%$ formamide/ $2 \times \mathrm{SSC}$ (saline sodium citrate), followed by a final dehydration. The SKY paints (Applied Spectral Imaging, Carlsbad CA) were denatured for $7 \mathrm{~min}$ at $75^{\circ} \mathrm{C}$, reannealed at $37^{\circ} \mathrm{C}$ for $1 \mathrm{hr}$, and then placed on the slide and covered with a glass coverslip. The coverslip was sealed with rubber cement, and hybridization was carried out in a humidified chamber for $24 \mathrm{hr}$ at $37^{\circ} \mathrm{C}$. Posthybridization washes were carried out according to established techniques and according to the manufacturer's instructions (Shrock et al., 1996). Images of metaphase chromosomes were captured for each preparation by use of an SD 200 spectral bio-imaging system (ASI Ltd., Migdal Haemek, Israel) attached to a Zeiss microscope (Axioplan 2) and stored on a SKY image-capture workstation. The passage number ( $\mathrm{p}$ ) and number of metaphase images captured and analyzed [in 
brackets] were as follows for each cell line: N15C6 p20 [10]; N15C6 p45 [10]; N17A3 p26 [10]; N33B2 p21 [9]; 1532T p44 [10]; and $1542 \mathrm{~T}$ p44 [10]. The images were analyzed with SKYView software (Applied Spectral Imaging). G-banding and SKY analyses were performed sequentially on each of the cell lines with the same 10 metaphase images captured for G-banding also analyzed by SKY.

\section{SNP Analysis}

Cells were grown to $90 \%$ confluency. Genomic DNA was harvested with use of the Wizard Genomic Purification Kit (Promega Corp., Madison, WI) according to the manufacturer's protocol. Allelic discrimination PCR was run by use of Assays on Demand FAM and VIC-labeled probes (Applied Biosystems, Foster City, CA) according to the manufacturer's protocols, with $13.5 \mathrm{ng}$ of genomic DNA as the template. The specific SNP assays used were: RANBP16, C_1959574_20; CISMD1， C_1423109_10; TACC1, C_11861239_10; NEFL， C_322260_10; RBPMS, C_15880850_10, and MSR1, C_12104846_10. All reactions were performed in triplicate, and no-template controls were included. Alleles for any locus (arbitrarily termed "A" or "B") were identified by the SNP assays from averaged intensity values from triplicate determinations after subtraction of no-template control values. The ratio of $\mathrm{B} / \mathrm{A}$ was interpreted to indicate two alleles at a given locus if $0.5<\mathrm{B} / \mathrm{A}<1.5$ (indicative of both alleles, $A B$ ). One allele was assessed if $\mathrm{B} / \mathrm{A}>1.5$ (indicative of the $\mathrm{B}$ allele) or if $\mathrm{B} / \mathrm{A}<$ 0.5 (indicative of the A allele).

\section{Affymetrix UI33A GeneChip Data Acquisition}

RNA was purified from histologically verified ( $>70 \%$ epithelial) normal human prostate tissues from three separate specimens or from trypsinized cultured cells by homogenization in Trizol (Invitrogen, Carlsbad, CA) and additional processing with the RNeasy (Qiagen, Valencia, CA) cleanup procedure. Ten micrograms of RNA obtained from tissues or cell lines was used to obtain labeled cRNA. Following an in vitro transcription reaction, the labeled cRNA was fragmented and then hybridized to Affymetrix U133A GeneChips (Affymetrix, Santa Clara, CA) for $16 \mathrm{hr}$ at $45^{\circ} \mathrm{C}$. The array was then washed and stained with streptavidin-phycoerythrin and scanned. Expression intensity values for each gene were estimated by a method called robust multiarray average (RMA), which is implemented in the Affymetrix library of the Bioconductor package for the statistical language R. This method uses a robust modeling strategy to estimate the average intensity of each gene on each chip. Detailed information can be found at http://www.bioconductor.org. GeneChip expression values were analyzed by use of a $t$-test-based analysis adjusted for false discovery rate (FDR) with the Significance Analysis of Microarrays (SAM) program (Tusher et al., 2001). The resulting data were organized by use of a hierarchical clustering scheme for grouping genes with similar expression patterns (Eisen et al., 1998). The distance metric used in the hierarchical clustering was the Pearson correlation.

\section{Quantitative Real-Time PCR}

All quantitative real-time assays were conducted with an Applied Biosystems 7900HT instrument and reagents. One microgram of RNA was reversetranscribed by use of Superscript III reverse transcriptase (Invitrogen, Carlsbad, CA). The resulting cDNA was diluted 1:100. Real-time PCR was performed by use of Assays on Demand (Applied BioSystems, Foster City, CA) according to the manufacturer's instructions, except that Real Time Ready with Rox passive dye (QBioGene, Carlsbad, CA) was used in place of TaqMan Universal PCR Master Mix. The FAM-conjugated, gene-specific assays were as follows: TNKS, Hs00186671_ml; MTUS1, Hs00368183_m1; NKX3.1, Hs00171834_m1; CLU, Hs00156548_m1; RBPMS, Hs00199302_m1; RCP, 0368787_m1; PPP2CB, Hs00602137_ml; TACC1, Hs00180691_ml; MYST3, Hs00198899_ml; IKBKB, Hs00395088_ml; RGS20, Hs00186596_m1; SNAI2, Hs00161904_m1; UBE2V2, Hs00163342_m1; MATN2, Hs00242767_m1, and the control RPLPO, Hs99999902_m1.

\section{Methylation Block}

Cells were grown to $\sim 50 \%$ confluency, then treated for 5 days with $5 \mu \mathrm{M}$ AAza-2-dCTP in $50 \%$ acetic acid (Sigma-Aldrich, St. Louis, MO) or acetic acid alone $(50 \mu \mathrm{l}$ in $5 \mathrm{ml}$ of medium; Mock treatment) in triplicate (Yamashita et al., 2002). RNA was prepared, and transcript levels for specific genes were assessed by use of quantitative real-time PCR. Statistical analysis was performed by ANOVA by use of averaged experimental (5Aza-dC) minus control (acetic acid) values.

\section{RESULTS}

\section{The Majority of Immortalized Prostate Epithelial Cells Exhibit 8p Loss}

Five cell lines were successfully developed from normal prostate epithelium through transduction with the pLXSN16E6E7 recombinant retrovirus. 
TABLE I. Chromosome 8 Configuration in HPV-Immortalized Cell Lines

\begin{tabular}{|c|c|c|c|c|}
\hline Cell line & Chromosome 8 configuration & $\begin{array}{l}\text { Number of } \\
\text { copies of } 8 p\end{array}$ & $\begin{array}{l}\text { Number of } \\
\text { copies of } 8 q\end{array}$ & Reference \\
\hline NI7A3 & two normal & 2 & 2 & This study \\
\hline I532T & one normal, one $\mathrm{i}(8)(\mathrm{q} \mid 0)$ & I & 3 & Macoska et al., 2000 \\
\hline I542T & $\begin{array}{l}\text { one } i(8)(8 q \mid 0) \text {, one } \operatorname{der}(8 ; 20)(q|0 ; p| 0) \text {, or } \\
\text { one } \operatorname{der}(8 ; 2 \mid)(q|0 ; p| 0)\end{array}$ & I & 3 & Macoska et al., 2000 \\
\hline N33B2 & $\begin{array}{l}\text { one normal, one } i(8)(q \mid 0) \\
\text { p20: one normal, } \\
\text { one } \operatorname{der}(8) t(8 ; \mid 9)(q|0 ; p| 0) \\
\text { two } \operatorname{der}(8) t(8 ; 20)(p|0 ; q| 0)\end{array}$ & I & 3 & This study \\
\hline NI5C6 & p45: one normal, one $\operatorname{der}(8 ; \mid 9)(q|0 ; q| 0)$ & I & 2 & Macoska et al., 2004 \\
\hline
\end{tabular}

Development and characterization of the $1532 \mathrm{~T}$, 1542T, and N15C6 cell lines were reported previously (Bright et al., 1997; Macoska et al., 2000, 2004; Schwab et al., 2000). The N17A3 and N33B2 cell lines are described here for the first time. The karyotypes for the $1532 \mathrm{~T}, 1542 \mathrm{~T}$, and N15C6 cell lines have been reported elsewhere (Macoska et al., 2000, 2004). The karyotypes for the remaining two cell lines are as follows: N17A3 (at passage 26, 10 cells analyzed), 34-48,X,Y, -11 (8/9 cells), -19 (7/9 cells), +20 (8/9 cells), -22 (8/9 cells), $\operatorname{der}(15) \mathrm{t}(11 ; 15)(\mathrm{q} 14 ; \mathrm{q} 24)(5 / 9$ cells); and N33B2 (at passage 21,9 cells analyzed), 40-44,X,Y, -19 (4/7 cells), -22 (5/7 cells), $\operatorname{der}(1) \mathrm{t}(1 ; 13)(\mathrm{p} 36 ; \mathrm{q} 32)(6 / 7$ cells), i(8q) (5/7 cells), $\operatorname{der}(13) \mathrm{t}(11 ; 13)(\mathrm{p} 10 ; \mathrm{q} 10)(2 /$ 7 cells), der(15)t(15;19)(q10;p10) (3/7 cells).

Two cell lines-N15C6 and 1542T-exhibited structural alterations of chromosome 8 that included translocation of chromosome 8 sequences to 19p (N15C6), 20q (1542T), or 21q (1542'T). Three cell lines-1532T, 1542T, and N33B2-exhibited $\mathrm{i}(8 \mathrm{q})$ chromosomes. Four of the six cell lines were hemizygous for the short arm of chromosome 8 (8p). The configuration of chromosomes 8 in each of the five cell lines is detailed in Table 1 and shown in Figure 1. Only the N17A3 cell line demonstrated two normal chromosomes 8. SNP analysis confirmed hemizygosity for all six SNP loci examined on 8p in the N33B2, N15C6, 1532'T, and $1542 \mathrm{~T}$ cell lines and heterozygosity for the MSR1, NEFL and TACC1 loci on $8 \mathrm{p}$ in the N17A3 cell line (Table 2).

\section{Gene Transcript Levels Are Proportional to Gene Dosage on Chromosome 8}

GeneChip expression values were compared between samples demonstrating two normal chromosomes 8 (the three normal prostate tissues and N17A3 cells) and those demonstrating derivative chromosomes 8 (N33B2, N15C6, 1532T, and $1542 \mathrm{~T}$ cells) by use of a $t$-test-based analysis adjusted for FDR with the Significance Analysis of Microarrays program. The FDR is equivalent to the $q$ value and is indicated as the $q$ value in Figure 2. The FDR ranged from $0.03 \%$ to $5.0 \%$. These analyses identified 125 differentially expressed transcripts specific to chromosome 8, with 46 localized to genes mapped to $8 \mathrm{p}$ and 79 localized to genes mapped to $8 \mathrm{q}$. The majority of transcripts mapping to $8 p(44 / 46$, 96\%) were significantly down-regulated in cells carrying derivative chromosomes 8 , and was consistent with reduction to hemizygosity for $8 \mathrm{p}$ in the N15C6, N33B2, $1532 \mathrm{~T}$, and $1542 \mathrm{~T}$ cell lines. This comparison also demonstrated that the majority of transcripts mapping to $8 \mathrm{q}(58 / 79,73 \%)$ were significantly up-regulated in cells carrying derivative chromosomes 8 (Fig. 2) compared to N17A3 cells and normal tissues.

To examine further the relationship of $8 \mathrm{q}$ dosage to $8 \mathrm{q}$ gene transcript levels, we performed an additional SAM analysis that focused exclusively on the transcriptional levels of genes mapping to $8 \mathrm{q}$. For these experiments, transcript levels for $8 \mathrm{q}$ genes were compared for N15C6 and N17A3 cells (both carrying 2 copies of $8 \mathrm{q}$ ) with N33B2 and $1532 \mathrm{~T}$ cells (both carrying 3 copies of $8 \mathrm{q}$ ). This analysis identified 41 differentially expressed genes on $8 \mathrm{q}$, with $34 / 41$ (83\%) up-regulated in N33B2 and 1532 T cells compared to N17A3 and N15C6 cells. The results of these studies are consistent with a concordant increased transcriptional level and increased gene dosage for genes mapping to $8 \mathrm{q}$ in N33B2 and 1532 T cells.

When organized by use of an unsupervised hierarchical clustering scheme with genes ordered based on chromosomal position (8pter-8qter), the gene expression data formed two large clusters, 
$1532 \mathrm{~T}$

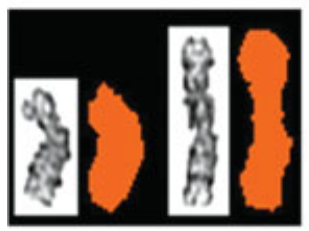

$\mathrm{i}(8)(q 10)$
$1542 T$

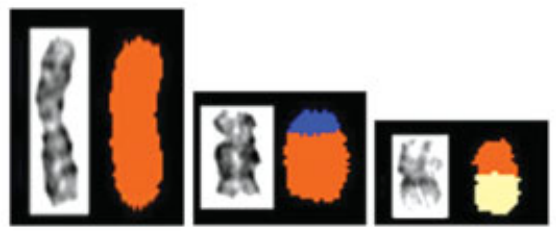

$i(8)(q 10), \operatorname{der}(8,20)(p 10 ; q 10)$,

$\operatorname{der}(8 ; 21)(p 10 ; q 10)$
N15C6p20

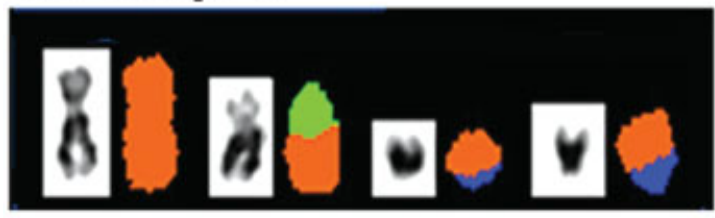

$\operatorname{der}(8) t(8 ; 19)(q 10 ; p 10)$, $+\operatorname{der}(8) t(8 ; 20)(p 10 ; q 10) \times 2$
N15C6p45

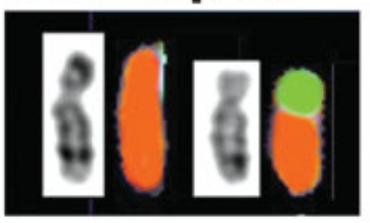

$\operatorname{der}(8 ; 19)(q 10 ; q 10)$
N33B2

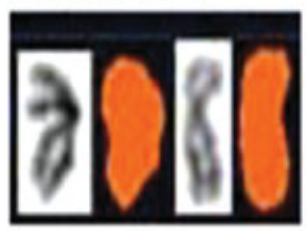

$i(8)(q 10)$

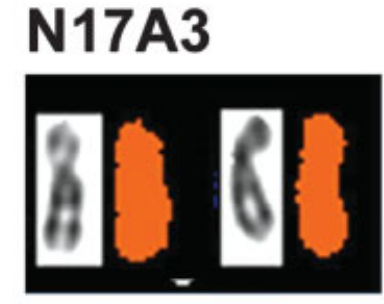

Figure I. Spectral karyotype analysis of derivative chromosomes 8 in immortalized human prostate epithelial cells. Chromosomes are shown both before (G-banded, left) and after (pseudo-color application, right) hybridization with wholechromosome paint probes. The compositions of derivative chromosomes 8 are indicated. Pseudo coloring indicates chromosome 8 in orange, chromosome 20 in blue; chromosome 21 in yellow, and chromosome 19 in green.
TABLE 2. SNP Allelotyping of Prostate Cell Lines

\begin{tabular}{lccccc}
\hline & \multicolumn{5}{c}{ Cell line } \\
\cline { 2 - 6 } Locus & NI7A3 & N33B2 & NI5C6 & I532T & I542T \\
\hline CSMD & $\mathrm{A}$ & $\mathrm{A}$ & $\mathrm{B}$ & $\mathrm{B}$ & $\mathrm{B}$ \\
MSRI & $\mathrm{AB}$ & $\mathrm{B}$ & $\mathrm{B}$ & $\mathrm{A}$ & $\mathrm{B}$ \\
NEFL & $\mathrm{AB}$ & $\mathrm{A}$ & $\mathrm{B}$ & $\mathrm{B}$ & $\mathrm{B}$ \\
RAN & $\mathrm{B}$ & $\mathrm{A}$ & $\mathrm{A}$ & $\mathrm{A}$ & $\mathrm{A}$ \\
RBPMS & $\mathrm{A}$ & $\mathrm{B}$ & $\mathrm{A}$ & $\mathrm{A}$ & $\mathrm{A}$ \\
TACCI & $\mathrm{AB}$ & $\mathrm{A}$ & $\mathrm{B}$ & $\mathrm{A}$ & $\mathrm{A}$ \\
\hline
\end{tabular}

Alleles at a locus have been designated as "A" or "B" according to these criteria: hemizygous for $B$ when $B / A>1.5$, hemizygous for $A$ when $B / A$ $<0.5$, and heterozygous when $0.5<\mathrm{B} / \mathrm{A}<\mathrm{I} .5$.

one comprising the three normal tissues and the N17A3 cells, which carried two normal chromosomes 8, and the other comprising the N33B2, N15C6, 1532T, and 1542'T cells, which carried derivative chromosomes 8 (Fig. 2). This result demonstrated that the observed trends in gene expression identified by the transcriptional profiles were largely consistent with the physical structure (normal or derivative) of the chromosomes 8 of the evaluated tissue or cell line. It should be noted that a large block of genes localized pericentromerically on 8 q11 were transcriptionally up-regulated in N33B2, 1532'T, and 1542'T, the three cell lines that were hemizygous for $8 \mathrm{p}$ and carrying $\mathrm{i}(8 \mathrm{q})$ chromosomes (Fig. 2).

Transcript Levels Are Frequently Reduced to Sub-Haploinsufficient Levels in Cells Hemizygous for $8 p$

The transcriptional levels of 14 genes-10 mapped to 8p (TNKS, MTUS1, NKX3.1, CLU, RBPMS, RCP, PP2CB, TACCI, MYST3, IKBKB) and 4 mapped to $8 \mathrm{q}$ (RGS20, SNAI2, UBE2V2, $M A T N 2)$-identified as differentially expressed in the GeneChip experiments were assessed by quantitative real-time PCR. As seen in Table 3, the expression trends for genes evaluated by both GeneChip and real-time PCR methodologies were similar. All 10 genes mapping to $8 \mathrm{p}$ were trans- 
Figure 2. Hierarchical clustering of chromosome 8 molecular signatures for prostate tissues and cell lines. Normal human prostate tissues and the NI7A3 immortalized human prostate epithelial cell line carry two normal chromosomes 8, whereas the N33B2, I542T, NI5C6, and $1532 \mathrm{~T}$ immortalized human prostate epithelial cell lines carry derivative chromosomes 8 . Normal human prostate tissues and the NI7A3 cell cluster together on the left; the N33B2, I542T, NI5C6, and I532T cell lines cluster together on the right of the diagram. Differentially expressed genes are designated by GenBank accession numbers and are arranged according to chromosomal position, from 8pter (top) to 8qter (bottom). Relative gene expression intensities are represented by color, with the highest expression indicated by light red and lowest expression by light green (see color bar). The data columns to the right of the heat map indicate the GenBank accession number, $t$ statistic, -fold change, $q$ value (false discovery rate) physical location on chromosome 8 in base pairs relative to 8pter (at 0 ), and expression trend for each gene. The physical location of the indicated genes is shown with reference to the chromosome 8 ideogram on the left.

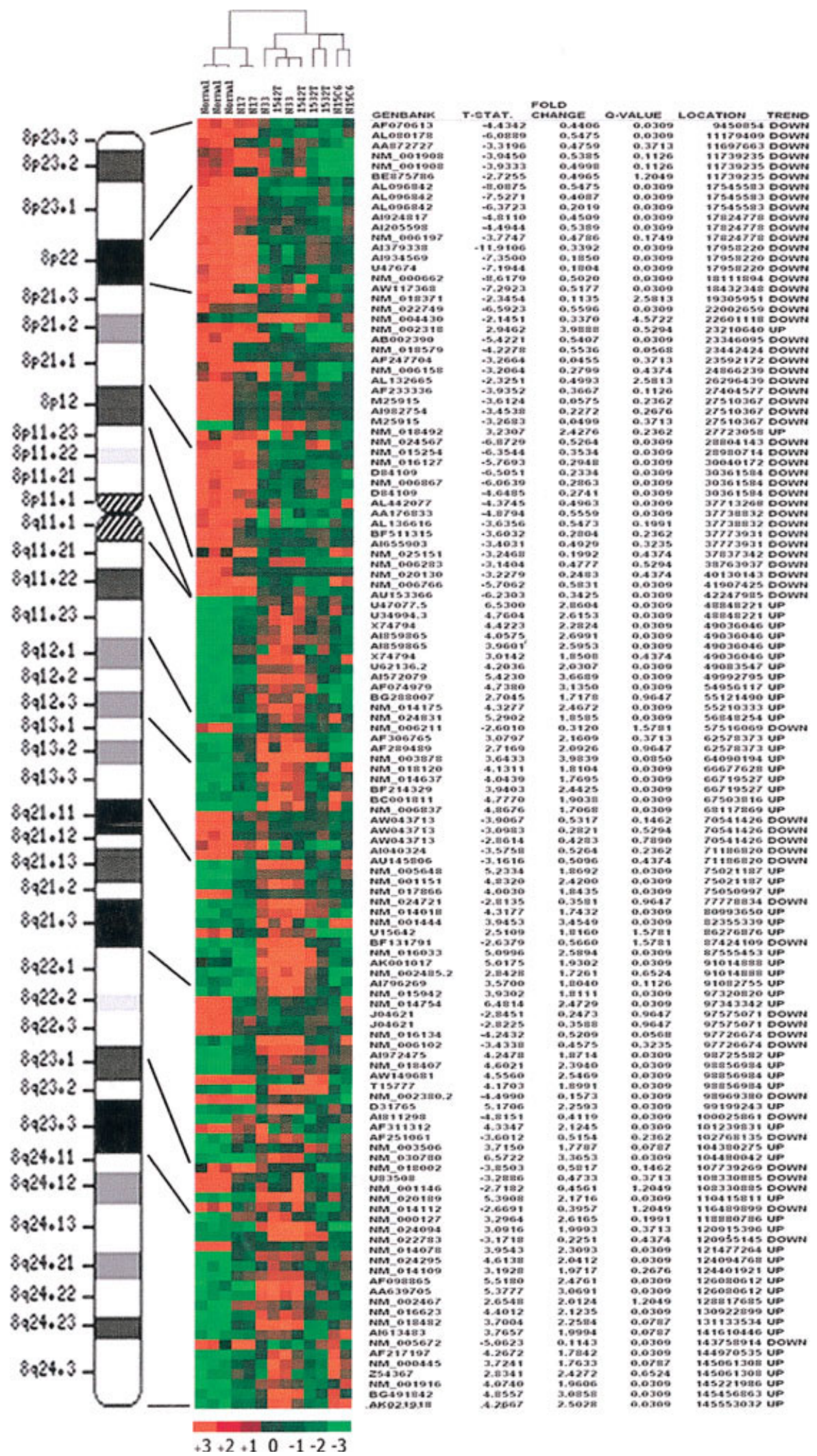


TABLE 3. Gene Expression Levels Relevant to Allelic Copy Number and Methylation Status

\begin{tabular}{|c|c|c|c|c|c|c|}
\hline $\mathrm{Gene}^{\mathrm{a}}$ & Cell line ${ }^{b}$ & $\begin{array}{l}\text { GeneChip } \\
\text { expression } \\
\text { Intensity }\end{array}$ & $\begin{array}{l}\text { GeneChip } \\
\text { relative } \\
\text { difference } \\
\text { from NI7A3 }\end{array}$ & $\begin{array}{c}\text { Real-time PCR } \\
\text { relative } \\
\text { difference } \\
\text { from NI7A3 }\end{array}$ & $\begin{array}{l}\text { Descriptive } \\
\text { expression } \\
\text { level }^{c}\end{array}$ & $\begin{array}{c}\text { Magnitude of } \\
\text { expression of } \\
\text { 5-Aza-dCTP/mock } \\
\text { treatment }^{d}\end{array}$ \\
\hline \multirow[t]{5}{*}{ TNKS 8p23.I } & NI7A3 & 8.5349 & & & Normal diploid & $1.27(0.16)$ \\
\hline & NI5C6 & 7.5549 & 0.51 & 0.22 & Haploinsufficient & $0.84(0.42)$ \\
\hline & N33B2 & 7.5700 & 0.51 & 0.09 & Haploinsufficient & $1.03(0.57)$ \\
\hline & $1532 T$ & 7.4964 & 0.50 & 0.50 & Haploinsufficient & $0.76(0.08)$ \\
\hline & $1542 \mathrm{~T}$ & 7.6001 & 0.52 & 0.45 & Haploinsufficient & $0.99(1.48)$ \\
\hline MTUSIIATIPIMTSGI & NI7A3 & 9.0427 & & & Normal diploid & $1.09(0.10)$ \\
\hline \multirow[t]{4}{*}{$8 p 22$} & NI5C6 & 8.1129 & 0.52 & 0.53 & Haploinsufficient & $0.84(0.02)$ \\
\hline & N33B2 & 7.0428 & 0.25 & 0.51 & Sub-haploinsufficient & $0.90(0.07)$ \\
\hline & I532T & 7.2312 & 0.28 & 0.62 & Sub-haploinsufficient & $0.8 \mathrm{I}(0.03)$ \\
\hline & $1542 \mathrm{~T}$ & 7.1544 & 0.27 & 0.52 & Sub-haploinsufficient & $0.94(0.04)$ \\
\hline \multirow[t]{5}{*}{ NKX3.I 8p21.2 } & NI7A3 & 8.7627 & & & Normal diploid & $0.96(0.10)$ \\
\hline & NI5C6 & 7.6702 & 0.47 & 0.42 & Haploinsufficient & $0.93(0.01)$ \\
\hline & N33B2 & 7.4763 & 0.41 & 0.59 & Haploinsufficient & $1.03(0.01)$ \\
\hline & $1532 T$ & 7.5506 & 0.43 & 0.62 & Haploinsufficient & $0.93(0.00)$ \\
\hline & I542T & 7.5211 & 0.42 & 0.46 & Haploinsufficient & $0.99(0.16)$ \\
\hline \multirow[t]{5}{*}{ CLU 8p2I.I } & NI7A3 & 9.7010 & & & Normal diploid & I. $18(0.02)$ \\
\hline & NI5C6 & 7.8431 & 0.28 & 0.23 & Sub-haploinsufficient & $1.38(0.01)$ \\
\hline & N33B2 & 7.8727 & 0.28 & 0.65 & Sub-haploinsufficient & $1.20(0.04)$ \\
\hline & I532T & 7.6853 & 0.25 & 0.42 & Sub-haploinsufficient & $1.15(0.14)$ \\
\hline & $1542 \mathrm{~T}$ & 8.0263 & 0.29 & 0.33 & Sub-haploinsufficient & $0.97(0.09)$ \\
\hline \multirow[t]{5}{*}{ RBPMS 8p 12} & NI7A3 & 7.8116 & & & Normal diploid & $1.17(0.96)$ \\
\hline & NI5C6 & 6.5243 & $0.4 I$ & 0.31 & Haploinsufficient & $\mathrm{I} .44(0.3 \mathrm{I})$ \\
\hline & N33B2 & 6.6881 & 0.46 & 0.80 & Haploinsufficient & $\mathrm{I} .14(0.49)$ \\
\hline & $1532 \mathrm{~T}$ & 7.0163 & 0.58 & 0.31 & Haploinsufficient & $\mathrm{I} .13(0.07)$ \\
\hline & $\mathrm{I} 542 \mathrm{~T}$ & 6.7768 & 0.49 & 0.39 & Haploinsufficient & $\mathrm{I} .35(0.07)$ \\
\hline \multirow[t]{5}{*}{$R C P$ 8p 12} & NI7A3 & 8.9545 & & & Normal diploid & $0.77(0.09)$ \\
\hline & NI5C6 & 8.0395 & 0.53 & 0.58 & Haploinsufficient & $0.99(0.10)$ \\
\hline & N33B2 & 6.7461 & 0.22 & 0.31 & Sub-haploinsufficient & $1.00(0.08)$ \\
\hline & I532T & 6.7558 & 0.22 & 0.26 & Sub-haploinsufficient & $0.93(0.09)$ \\
\hline & $\mathrm{I} 542 \mathrm{~T}$ & 7.0416 & 0.27 & 0.06 & Sub-haploinsufficient & $0.83(0.03)$ \\
\hline \multirow[t]{5}{*}{ PPP2CB 8p 12} & NI7A3 & II.4297 & & & Normal diploid & $0.84(0.17)$ \\
\hline & NI5C6 & 11.1333 & 0.81 & 0.33 & Haploinsufficient & $1.03(0.48)$ \\
\hline & N33B2 & 10.8176 & 0.65 & 0.40 & Haploinsufficient & $0.66(0.01)$ \\
\hline & $1532 \mathrm{~T}$ & 10.6311 & 0.57 & 0.40 & Haploinsufficient & $1.25(0.92)$ \\
\hline & $1542 \mathrm{~T}$ & 10.9211 & 0.70 & 0.19 & Haploinsufficient & $1.60(0.22)$ \\
\hline \multirow[t]{5}{*}{ TACCI 8pII.23 } & NI7A3 & 8.7967 & & & Normal diploid & $1.80(0.11)$ \\
\hline & NI5C6 & 7.8278 & 0.51 & 0.50 & Haploinsufficient & $1.08(0.14)$ \\
\hline & N33B2 & 8.2347 & 0.68 & 0.02 & Haploinsufficient & I.6I (0.96) \\
\hline & I532T & 7.8839 & 0.53 & 0.80 & Haploinsufficient & $1.50(1.07)$ \\
\hline & I542T & 8.4415 & 0.78 & 0.84 & Elevated & $0.67(0.20)$ \\
\hline \multirow[t]{5}{*}{ MYST3 8p I I.2I } & NI7A3 & $|0.344|$ & & & Normal diploid & $0.82(0.09)$ \\
\hline & NI5C6 & 9.9824 & 0.78 & 0.51 & Haploinsufficient & $1.23(0.50)$ \\
\hline & N33B2 & 9.5280 & 0.57 & 0.27 & Haploinsufficient & $0.90(0.07)$ \\
\hline & I532T & 9.3938 & 0.52 & 0.26 & Haploinsufficient & I. $18(0.06)$ \\
\hline & I542T & 9.4300 & 0.53 & 0.54 & Haploinsufficient & $1.89(0.36)$ \\
\hline \multirow[t]{5}{*}{ IKВKB 8p I I.2I } & NI7A3 & 7.3251 & & & Normal diploid & $0.99(0.08)$ \\
\hline & NI5C6 & 6.6220 & 0.61 & 0.43 & Haploinsufficient & $1.09(0.02)$ \\
\hline & N33B2 & 6.6027 & 0.61 & 0.41 & Haploinsufficient & $1.03(0.05)$ \\
\hline & $1532 \mathrm{~T}$ & 6.4703 & 0.55 & 0.33 & Haploinsufficient & $1.13(0.03)$ \\
\hline & $1542 \mathrm{~T}$ & 6.6620 & 0.63 & 0.56 & Haploinsufficient & $\mathrm{I} .08(0.05)$ \\
\hline \multirow[t]{5}{*}{ RGS20 8q I I.23 } & NI7A3 & 6.4388 & & & & $1.08(0.08)$ \\
\hline & NI5C6 & 7.3215 & 1.84 & 1.47 & & $1.20(0.08)$ \\
\hline & N33B2 & $8.7|3|$ & 4.84 & 1.90 & & $1.05(0.03)$ \\
\hline & I532T & 8.0973 & 3.16 & 1.85 & & $1.16(0.02)$ \\
\hline & $1542 \mathrm{~T}$ & 8.7364 & 4.92 & 15.38 & & $1.22(0.06)$ \\
\hline \multirow[t]{3}{*}{ SNAI2 8q II.2I } & NI7A3 & 9.3423 & & & & $\mathrm{I} .10(0.3 \mathrm{I})$ \\
\hline & NI5C6 & |I.2486 & 3.75 & 1.12 & & $2.68(0.14)$ \\
\hline & N33B2 & 11.8038 & 5.51 & 9.88 & & $1.84(0.15)$ \\
\hline
\end{tabular}


TABLE 3. Gene Expression Levels Relevant to Allelic Copy Number and Methylation Status (Continued)

\begin{tabular}{|c|c|c|c|c|c|c|}
\hline $\mathrm{Gene}^{\mathrm{a}}$ & Cell line ${ }^{b}$ & $\begin{array}{l}\text { GeneChip } \\
\text { expression } \\
\text { Intensity }\end{array}$ & $\begin{array}{l}\text { GeneChip } \\
\text { relative } \\
\text { difference from } \\
\text { NI7A3 }\end{array}$ & $\begin{array}{c}\text { Real-time PCR } \\
\text { relative } \\
\text { difference } \\
\text { from } \mathrm{N} I 7 \mathrm{~A} 3\end{array}$ & $\begin{array}{c}\text { Descriptive } \\
\text { expression } \\
\text { level }^{c}\end{array}$ & $\begin{array}{c}\text { Magnitude of } \\
\text { expression of } \\
\text { 5-Aza-dCTP/mock } \\
\text { treatment }^{\mathrm{d}}\end{array}$ \\
\hline & $\mathrm{I} 532 \mathrm{~T}$ & | I.394| & 4.15 & 1.03 & & $1.57(0.12)$ \\
\hline & $\mathrm{I} 542 \mathrm{~T}$ & | I.965| & 6.16 & 8.26 & & $0.64(0.04)$ \\
\hline \multirow[t]{5}{*}{ UBE2V2 8q I. } & NI7A3 & 8.9640 & & & & $1.16(0.21)$ \\
\hline & NI5C6 & 10.0513 & 2.12 & 2.73 & & $1.35(0.12)$ \\
\hline & N33B2 & 10.3167 & 2.55 & 2.09 & & $1.31(0.08)$ \\
\hline & $1532 \mathrm{~T}$ & 9.8244 & 1.82 & 1.78 & & $1.74(0.09)$ \\
\hline & $1542 \mathrm{~T}$ & 10.4446 & 2.79 & 1.00 & & $\mathrm{I} .84(0.27)$ \\
\hline \multirow[t]{5}{*}{ MATN2 8q22 } & NI7A3 & 9.4594 & & & & $0.70(0.04)$ \\
\hline & NI5C6 & 6.2641 & 0.11 & 0.82 & & $0.77(0.02)$ \\
\hline & N33B2 & 6.4067 & 0.12 & 0.20 & & $0.84(0.04)$ \\
\hline & $\mathrm{I} 532 \mathrm{~T}$ & 8.5334 & 0.53 & 0.12 & & $0.79(0.02)$ \\
\hline & $\mathrm{I} 542 \mathrm{~T}$ & 6.7616 & 0.15 & 0.30 & & $0.81(0.02)$ \\
\hline
\end{tabular}

${ }^{\mathrm{a} G e n e}$ symbol and cytogenetic location are shown.

${ }^{b} \mathrm{NI7A3}$ cells possess two copies of 8p, whereas NI5C6, N33B2, I532T, and I542T cells possess one copy of 8p.

${ }^{c}$ For cells with one copy of $8 p$, haploinsufficient levels are defined as between 0.70 and 0.30 of normal, sub $=$ haploinsufficient as $<0.30$ of normal, and elevated as $>0.70$ of normal.

${ }^{\mathrm{d}}$ Gene expression is expressed as a ratio of that obtained for cells grown in 5 mM 5-Aza-2-dCTP and that for mock-treated cells (standard deviation is shown in parentheses).

criptionally down-regulated in the majority of cell lines hemizygous for $8 \mathrm{p}$, compared to those heterozygous for $8 \mathrm{p}$. However, the transcriptional profiles for each gene in each cell line hemizygous for $8 p$ were somewhat heterogeneous and varied from haploinsufficient or sub-haploinsufficient levels to elevated levels. For example, after normalization to N17A3 transcript levels as a measure of normal heterozygous transcriptional activity, it was apparent that all cell lines hemizygous for $8 \mathrm{p}$ expressed NKX3.1 at haploinsufficient levels, that is, between 0.41 - and 0.47 -fold of that observed for N17A3 cells by GeneChip analysis. In contrast, all cells hemizygous for $8 \mathrm{p}$ expressed $C L U$ at sub-haploinsufficient levels, between 0.25and 0.29 -fold of that observed for N17A3 cells. TNKS, MTUS1, RBPMS, RCP, and IKBKB were expressed at haploinsufficient or sub-haploinsufficient levels in cells hemizygous for $8 \mathrm{p}$. Expression levels of $P P 2 C B, T A C C 1$, and MYST3 were haploinsufficient for three of four cell lines hemizygous for $8 p$, but were elevated, that is, expressed at nearheterozygous levels, in one of the four cell lines (Table 3). In total, transcript levels were measured in 40 instances (4 cell lines hemizygous for 8p, 10 genes evaluated by quantitative real-time PCR) and were found to be haploinsufficient in $27 / 40$ instances (68\%), sub-haploinsufficient in 10/40 instances $(25 \%)$, and elevated in $3 / 40$ instances (8\%) by GeneChip analysis. These observations demonstrate that transcript levels were reduced to haploinsufficient or sub-haploinsufficient levels in the majority $(37 / 40,92 \%)$ of the cases examined in this study.

\section{Epigenetic Mechanisms May Regulate Transcription of Hemizygous 8p Genes}

The observed sub-haploinsufficient transcript levels for three genes-MTUS1, CLU, and RCPmapping to $8 \mathrm{p}$ in cells hemizygous for the same sequences could be attributed to epigenetic mechanisms. To investigate this question, we grew cells heterozygous (N17A3) or hemizygous (N15C6, $\mathrm{N} 33 \mathrm{~B} 2,1532 \mathrm{~T}, 1542 \mathrm{~T}$ ) for $8 \mathrm{p}$ in the presence of the methylation blocking agent 5Aza-2-dCTP or, as a control, in the vehicle solvent acetic acid. Of the 10 genes examined, exposure to the methylation blocking agent was associated with significantly increased transcript expression of MTUS1, $C L U$, and $R C P$ in three or more cell lines hemizygous for $8 \mathrm{p}$ (Table 3 ). For genes mapping to $8 \mathrm{q}$, none of the three genes that exhibited increased transcript levels compared to N17A3 cells by Gene Chip and quantitative RT-PCR analyses demonstrated significantly higher expression levels in more than two cell lines after treatment with the hypomethylating agent. In contrast, MATN2, which maps to $8 \mathrm{q}$ but exhibited decreased transcript levels compared to N17A3 cells by both gene expression profiling and quantitative RT-PCR studies, demonstrated significantly increased transcript levels in N15C6, N33B2, and 1542'T cells after treatment with 5Aza-2-dCTP (Table 3). These data suggest that both allelic deletion and sequence 
methylation may contribute to the transcriptional silencing of particular genes in immortalized and initially transformed human prostate cells.

\section{DISCUSSION}

Loss of $8 p$ and gain of $8 q$ are observed frequently in human prostate tumors. These observations are consistent with the hypothesis that tumor-suppressor genes mapping to $8 \mathrm{p}$ and oncogenes mapping to $8 \mathrm{q}$ play critical roles in prostate cellular immortalization and transformation. However, identifying specific genes that function as tumor-suppressor genes or oncogenes mapping to chromosome 8 has been difficult and labor intensive. We have attempted to address these issues by utilizing a high-throughput approach to identifying candidate tumor-suppressor genes and oncogenes associated with DNA sequences losses or gains, respectively, on chromosome 8 .

Examination of the transcriptional profiles of prostate tissues and cell lines possessing two normal chromosomes 8 and of those possessing derivative chromosomes 8 revealed large-scale transcriptional up-regulation of genes mapping to $8 \mathrm{q}$. Three of the four cell lines exhibiting derivative chromosomes $8-\mathrm{N} 33 \mathrm{~B} 2,1532 \mathrm{~T}$, and $1542 \mathrm{~T}$ - carry i(8q) chromosomes with consequent gain of $8 \mathrm{q}$. Moreover, specific "blocks" of increased gene transcription were evident on the $8 \mathrm{q}$ arm. Notably, a large block of 20 genes localized pericentromerically on $8 \mathrm{q}$ was transcriptionally up-regulated in the four cell lines carrying derivative chromosomes 8 (Fig. 2). This suggests that long-range chromatin modifications may occur because of reduction to hemizygosity for $8 \mathrm{p}$ that result in increased transcriptional activity of pericentromeric genes. Other blocks of transcriptionally up-regulated genes on $8 \mathrm{q}$, including one at $8 \mathrm{q} 22$ and most of the $8 \mathrm{q} 24$ region, are consistent with sites for putative oncogenes (Rubin, 2004; Savinainen, 2004; Wang, 2004).

Four of the five immortalized prostate epithelial cell lines utilized in the studies reported here were hemizygous for $8 \mathrm{p}$ and demonstrated transcriptional down-regulation for the majority (96\%) of genes mapping to $8 \mathrm{p}$. These four cell lines clustered with each other in the dendrogram shown in Figure 2, suggesting that they shared a common transcriptional molecular signature largely driven by hemizygosity for $8 \mathrm{p}$. In the majority $(68 \%)$ of cases examined, hemizygosity for $8 \mathrm{p}$ was associated with haploinsufficient transcript levels, that is, levels that were approximately half that observed for cells possessing two copies of $8 \mathrm{p}$ ('Table 3). However, an additional $25 \%$ of cases examined demonstrated transcript levels that were further reduced to sub-haploinsufficient levels (Table 3). This finding suggested that some of the genes mapping to the sole copy of $8 \mathrm{p}$ in these cells might be transcriptionally inactivated through epigenetic mechanisms. Indeed, induction of a methylation block resulted in significantly increased expression of all transcripts detected at sub-haploinsufficient levels by GeneChip analysis. The results of these studies clearly demonstrated that methylationmediated epigenetic regulation could be responsible for the observed sub-haploinsufficient $8 \mathrm{p}$ hemizygous allele transcript levels in immortalized and initially transformed prostate epithelial cells.

Surprisingly, transcripts originating from $8 p$ hemizygous alleles were actually elevated above haploinsufficient levels in 3 of $40(8 \%)$ of cases examined. This phenomenon was largely heterogeneous, and was observed for three genesPPP2CB, TACC1, and MYST3-in one cell line each. $P P P 2 C B$ was recently found to be downregulated in a majority of prostate tumors examined but up-regulated in a minority of cases (Wissmann et al., 2003). TACC1 has been described as transcriptionally down- and up-regulated in human breast tumors, the latter in conjunction with DNA amplification (Conte et al., 2002; Ray et al., 2004). Although transcript expression of MYST3 has not been previously reported for prostate tissues, MYST3 is involved in $\mathrm{t}(8 ; 16)(\mathrm{p} 11 ; \mathrm{p} 13)$ translocations and forms a fusion protein with $C R E B B P$ that is frequently associated with acute myeloid leukemia (Rozman et al., 2004). A survey of gene expression profiles of normal and malignant prostate tissues identified down-regulation for MYST3 in three studies, up-regulation in one study, and lack of differential expression in four other studies (http:// www.oncomine.org). These reports suggest that these three genes in particular may be subject to complex transcriptional and translational regulation in human prostate cells.

The observation of both haploinsufficient and sub-haploinsufficient transcript levels originating from hemizygous alleles of $8 \mathrm{p}$-localized genes further suggests that deletion of one copy of $8 \mathrm{p}$ may result in either a one-hit or a two-hit mechanism for tumor initiation or progression. This hypothesis proposes that cells suffering deletion of one copy of $8 \mathrm{p}$ and expressing haploinsufficient levels of associated transcripts may be preferentially selected for clonal growth and immortalization, whereas similar cells that experience further transcript reductions to sub-haploinsufficient levels may be driven further down the road of malignant progres- 
sion. This is a difficult hypothesis to test because of the typical presence of several genetic alterations in addition to $8 \mathrm{p}$ loss in cultured cells and tumors. However, evaluation of the simple cultured-cell models used in the current study showed that N33B2, 1532'T, and 1542'T cells exhibited subhaploinsufficient levels of 3 of the 10 genes examined on 8p, whereas N15C6 cells exhibited subhaploinsufficient levels of only 1 of the same 10 genes (Table 3). Moreover, previous studies have shown that $1532 \mathrm{~T}$ and $1542 \mathrm{~T}$ cells express a more advanced malignant phenotype than do N15C6 cells (Schwab et al., 2000; Macoska et al., 2000, 2004).

Taken together, these observations are consistent with a positive correlation between advanced expression of the malignant phenotype and sub-haploinsufficient levels of hemizygous $8 \mathrm{p}$ gene transcript levels. This is an interesting hypothesis that will require the study of more refined, gene-specific models for thorough testing and evaluation.

\section{REFERENCES}

Asatiani E, Huang WX, Wang A, Rodriguez Ortner E, Cavalli LR, Haddad BR, Gelmann EP. 2005. Deletion, methylation, and expression of the NKX3.1 suppressor gene in primary human prostate cancer. Cancer Res 65:1164-1173.

Bergerheim USR, Kunimi K, Collins VP Ekman, P. 1991. Deletion mapping of chromosomes 8,10 , and 16 in human prostatic carcinoma. Genes Chromosomes Cancer 3:225-220.

Bova GS, Carter BS, Bussemakers JG, Emi M, Fujiwara Y, Kyprianou N, Jacobs SC, Robinson JC, Epstein JI, Walsh PC. 1993. Homozygous deletion and frequent allelic loss of chromosome 8p22 loci in human prostate cancer. Cancer Res 53:38693873 .

Bova GS, MacGrogan D, Levy A, Pin SS, Bookstein R, Isaacs WB. 1996. Physical mapping of chromosome 8p22 markers and their homozygous deletion in a metastatic prostate cancer. Genomics 35:46-54

Bright RK, Vocke CD, Emmert-Buck MR, Duray PH, Solomon D, Fetsch P, Rhim JS, Linehan WM, Topalian SL. 1997. Generation and genetic characterization of immortal human prostate epithelial cell lines derived from primary cancer specimens. Cancer Res 57:995-1002.

Chaib H, MacDonald JW, Vessella RL, Washburn JG, Quinn JE, Oldman A, Rubin MA, Macoska JA. 2003. Haploinsufficiency and reduced expression of 8 p-localized genes in human prostate tumors. Genes Chromosomes Cancer 37:306-313.

Conte N, Charafe-Jauffret E, Delaval B, Adelaide J, Ginestier C, Geneix J, Isnardon D, Jacquemier J, Birnbaum D. 2002. Carcinogenesis and translational controls: TACC1 is down-regulated in human cancers and associates with mRNA regulators. Oncogene 21:5619-5630.

Eisen MB, Spellman PT, Brown PO, Botstein D. 1998. Cluster analysis and display of genome-wide expression patterns. Proc Natl Acad Sci USA 95:14863-14868.

Haggman MJ, Wojno KJ, Pearsall CP, Macoska JA. 1997. Allelic loss of $8 \mathrm{p}$ sequences in prostatic intraepithelial neoplasia and carcinoma. Urology 50:643-647.

He WW, Sciavolino PJ, Wing J, Augustus M, Hudson P, Meissner PS, Curtis RT, Shell BK, Bostwick DG, Tindall DJ et al. 1997. A novel human prostate-specific, androgen-regulated homeobox gene (NKX3.1) that maps to $8 \mathrm{p} 21$, a region frequently deleted in prostate cancer. Genomics 43:69-77.

Ishii H, Baffa R, Numata SI, Murakumo Y, Rattan S, Inoue H, Mori M, Fidanza V, Alder H, Croce CM. 1999. The FEZ1 gene at chromosome 8p22 encodes a leucine-zipper protein, and its expression is altered in multiple human tumors. Proc Natl Acad Sci USA 96:3928-3933.
Jenkins RB, Qian J, Lieber MM, Bostwick DG. 1997. Detection of c-myc oncogene amplification and chromosomal anomalies in metastatic prostatic carcinoma by fluorescence in situ hybridization. Cancer Res 57:524-531.

July LV, Akbari M, Zellweger T, Jones EC, Goldenberg SL, Gleave ME. 2002. Clusterin expression is significantly enhanced in prostate cancer cells following androgen withdrawal therapy. Prostate 50:179-188.

Knudson AG. 1971. Mutation and cancer: statistical study of retinoblastoma. Proc Natl Acad Sci USA 68:820-823.

MacGrogan D, Levy A, Bostwick D, Wagner M, Wells D, Bookstein R. 1994. Genes Chromosomes Cancer 10:151-159.

Macoska JA, Micale MA, Sakr WA, Benson PD, Wolman SR. 1993. Extensive genetic alterations in prostate cancer revealed by dual PCR and FISH analysis. Genes Chromosomes Cancer 8:8897.

Macoska JA, Trybus TM, Sakr WA, Wolf MC, Benson PD, Powell IJ, Pontes JE. 1994. Fluorescence in situ hybridization (FISH) analysis of 8 p allelic loss and chromosome 8 instability in human prostate cancer. Cancer Res 54:3824-3830.

Macoska JA, Trybus TM, Benson PD, Sakr WA, Grignon DJ, Wojno KD, Pietruk T, Powell IJ. 1995. Evidence for three tumor suppressor gene loci on chromosome $8 \mathrm{p}$ in human prostate cancer. Cancer Res 55:5390-5395.

Macoska JA, Beheshti B, Rhim JS, Hukku B, Lehr J, Pienta KJ, Squire JA. 2000. Genetic characterization of immortalized human prostate epithelial cell cultures: Evidence for structural rearrangements of chromosome 8 and $\mathrm{i}(8 \mathrm{q})$ chromosome formation in primary tumor-derived cells. Cancer Genet Cytogenet 120: 50-57.

Macoska JA, Paris P, Collins C, Andaya A, Beheshti B, Chaib H, Kant R, Begley L, MacDonald JW, Squire JA. 2004. Evolution of $8 \mathrm{p}$ loss in transformed human prostate epithelial cells. Cancer Genet Cytogenet 154:36-43.

Matsutani N, Yokozaki H, Tahara E, Tahara H, Kuniyasu H, Haruma K, Chayama K, Yasui W, Tahara E. 2001. Expression of telomeric repeat binding factor 1 and 2 and TRF1-interacting nuclear protein 2 in human gastric carcinomas. Int J Oncol 19: 507-512.

Ornstein DK, Cinquanta M, Weiler S, Duray PH, Emmert-Buck MR, Vocke CD, Linehan WM, Ferretti JA. 2001. Expression studies and mutational analysis of the androgen regulated homeobox gene NKX3.1 in benign and malignant prostate epithelium. J Urol 165:1329-1334.

Prasad MA, Trybus TM, Wojno KJ, Macoska JA. 1998. Homozygous and frequent deletion of proximal 8 p sequences in human prostate cancers: identification of a potential tumor suppressor gene site. Genes Chromosomes Cancer 23:255-262.

Qian J, Bostwick DG, Takahashi S, Borell TJ, Herath JF, Lieber MM, Jenkins RB. 1995. Chromosomal anomalies in prostatic intraepithelial neoplasia and carcinoma detected by fluorescence in situ hybridization. Cancer Res 55:5408-5414.

Ray ME, Yang ZQ, Albertson D, Washburn JG, Macoska JA, Ethier SP. 2004. Genomic and expression analysis of the 8p11-12 amplicon in human breast cancer cell lines. Cancer Res 64:40-47.

Rozman M, Camos M, Colomer D, Villamor N, Esteve J, Costa D, Carrio A, Aymerich M, Aguilar JL, Domingo A, Sole F, Gomis F, Florensa L, Montserrat E, Campo E. 2004. Type I MOZ/CBP MYST3/CREBBP) is the most common chimeric transcript in acute myeloid leukemia with $\mathrm{t}(8 ; 16)(\mathrm{p} 11 ; \mathrm{p} 13)$ translocation. Genes Chromosomes Cancer 40:140-145.

Rubin MA, Varambally S, Beroukhim R, Tomlins SA, Rhodes DR, Paris PL, Hofer MD, Storz-Schweizer M, Kuefer R, Fletcher JA, Hsi BL, Byrne JA, Pienta KJ, Collins C, Sellers WR, Chinnaiyan AM. 2004. Overexpression, amplification, and androgen regulation of TPD52 in prostate cancer. Cancer Res 64:3814-3822.

Sakr WA, Macoska JA, Benson PD, Grignon DJ, Wolman SR, Pontes JE, Crissman JD. 1994. Allelic loss in locally metastatic multisampled prostate cancer. Cancer Res 54:3273-3277.

Sato K, Qian J, Slezak JM, Lieber MM, Bostwick DG, Bergstralh EJ, Jenkins RB. 1999. Clinical significance of alterations of chromosome 8 in high-grade, advanced, nonmetastatic prostate carcinoma. J Natl Cancer Inst 91:1574-1580.

Schrock E, Veldman T, Padilla-Nash H, Ning Y, Spurbeck J, Jalal S, Shaffer LG, Papenhausen P, Kozma C, Phelan MC, Kjeldsen E, Schonberg SA, O’Brien P, Biesecker L, du Manoir S, Ried T. 1996. Multicolor spectral karyotyping of human chromosomes. Science 273:494-497.

Schwab TR, Stewart TJ, Lehr J, Pienta KJ, Rhim JS, Macoska JA. 2000. Phenotypic characterization of immortalized normal and 
primary tumor-derived human prostate epithelial cell cultures. The Prostate 44:164-171.

Takahashi S, Qian J, Brown JA, Alcaraz A, Bostwick DG, Lieber MM, Jenkins RB. 1994. Potential markers of prostate cancer aggressiveness detected by fluorescence in situ hybridization in needle biopsies. Cancer Res 54:3574-3549.

Trapman J, Sleddens HFBM, van der Weiden MM, Dinjens WNM, Konig JJ, Schroder FH, Faber PW, Bosman FT. 1994. Loss of heterozygosity of chromosome 8 microsatellite loci implicates a candidate tumor suppressor gene between the loci D8S87 and D8S133 in human prostate cancer. Cancer Res 54:6061-6064.

Tusher G, Tibshirani R, Chu G. 2001. Significance analysis of microarrays applied to the ionizing radiation response. Proc Natl Acad Sci USA 98:5116-5121.

Wang R, Xu J, Saramaki O, Visakorpi T, Sutherland WM, Zhou J, Sen B, Lim SD, Mabjeesh N, Amin M, Dong JT, Petros JA, Nelson PS, Marshall FF, Zhau HE, Chung LW. 2004. PrLZ, a novel prostate-specific and androgen-responsive gene of the TPD52 family, amplified in chromosome $8 \mathrm{q} 21.1$ and overexpressed in human prostate cancer. Cancer Res 64:1589-1594.
Wolman SR, Macoska JA, Micale MA, Sakr WA. 1992. An approach to definition of genetic alterations in prostate cancer. Diag Mol Path 1:192-199.

Xu J, Zheng SL, Komiya A, Mychaleckyj JC, Isaacs SD, Hu JJ, Sterling D, Lange EM, Hawkins GA, Turner A, Ewing CM, Faith DA, Johnson JR, Suzuki H, Bujnovszky P, Wiley KE, DeMarzo AM, Bova GS, Chang B, Hall MC, McCullough DL, Partin AW, Kassabian VS, Carpten JD, Bailey-Wilson JE, Trent JM, Ohar J, Bleecker ER, Walsh PC, Isaacs WB, Meyers DA. 2002. Germline mutations and sequence variants of the macrophage scavenger receptor 1 gene are associated with prostate cancer risk. Nat Genet 32:321-325.

Wissmann C, Wild PJ, Kaiser S, Roepcke S, Stoehr R, Woenckhaus M, Kristiansen G, Hsieh JC, Hofstaedter F, Hartmann A, Knuechel R, Rosenthal A, Pilarsky C. 2003. WIF1, a component of the Wnt pathway, is down-regulated in prostate, breast, lung, and bladder cancer. J Pathol 201:204-12.

Yamashita K, Upadhyay S, Osada M, Hoque MO, Xiao Y, Mori M, Sato F, Meltzer SJ, Sidransky D. 2002. Pharmacologic unmasking of epigenetically silenced tumor suppressor genes in esophageal squamous cell carcinoma. Cancer Cell 2:485-495. 